\title{
THE ISSUE OF ACTIVE AGEING AND ACTIVE OLD AGE IN THE EDUCATION AND SOCIAL POLICY OF SLOVAKIA, GERMANY AND SPAIN
}

\author{
Ctibor Határ ${ }^{1}$, Petra Jedličková1 \\ ${ }^{1}$ Constantine the Philosopher University, Faculty of Education, Department of \\ Pedagogy, Dražovská 4, 94974 Nitra, Slovak Republic \\ Link to this article: https://doi.org/10.11118/lifele20201003311 \\ Podáno: 15. 4. 2020, Přijato: 24. 9. 2020 \\ To cite this article: HATÁR CTIBOR, JEDLIČKOVÁ PETRA. 2020. The issue of \\ active ageing and active old age in the education and social policy of Slovakia, \\ Germany and Spain. Lifelong Learning - celoživotní vzdělávání, 10 (3): 311-331.
}

\begin{abstract}
The presented study is the output of the authors from solving the research project VEGA no. 1/0001/18 called Preparation for ageing and old age - possibilities of andragogical intervention. Based on the planned aims of the project, the authors deal with the analysis of the education and social policies of selected states of the European Union to identify those areas which are related to active ageing and active old age. Subsequently, they compare the Slovak education and social policy to foreign education and social ones on the state level, focusing on the topics of active ageing and active old age. The methodology of the research work of the authors lies in the national documents and their subsequent comparing. The authors identified common aspects of the education and social policies of the selected states of the European Union (Slovakia, Germany and Spain) in the given parameters or areas (active ageing and active old age).
\end{abstract}


Keywords: active ageing, active old age, education and social policy, Slovakia, Germany, Spain

\title{
PROBLEMATIKA AKTÍVNEHO STARNUTIA A AKTÍVNEJ STAROBY VO VZDELÁVACEJ A SOCIÁLNEJ POLITIKE SLOVENSKA, NEMECKA A ŠPANIELSKA
}

\begin{abstract}
Abstrakt
Predkladaná štúdia je výstupom autorov z riešenia výskumného projektu VEGA č. 1/0001/18 s názvom Príprava na starnutie a starobu - možnosti andragogickej intervencie. Autori sa na základe plánovaných cielov projektu venujú analýze vzdelávacej a sociálnej politiky vybraných štátov Európskej únie s ciel'om identifikovat' tie oblasti, ktoré sa viažu k aktívnemu starnutiu a k aktívnej starobe, a následne porovnávajú slovenskú štátnu vzdelávaciu a sociálnu politiku s akcentom na otázky aktívneho starnutia a aktívnej staroby so zahraničnou vzdelávacou a sociálnou politikou na úrovni štátu. Metodika výskumnej práce autorov vychádza z princípov porovnávacej andragogiky. Obsahovou analýzou národných dokumentov a ich následným porovnaním autori identifikovali spoločné znaky vzdelávacej a sociálnej politiky vybraných štátov Európskej únie (Slovensko, Nemecko a Španielsko) v sledovaných parametroch, resp. oblastiach (aktívne starnutie a aktívna staroba).
\end{abstract}

Klúčové slová: aktívne starnutie, aktívna staroba, vzdelávacia a sociálna politika, Slovensko, Nemecko, Španielsko 
The issue of active ageing and active old age in the education and social policy ...

\section{INTRODUCTION}

Education and social policies are frequently used concepts in every period and almost in every country. There exists a particular connection between the two mentioned types. The social one also subsumes the education policy under its scope (e.g. compare Stanek et al., 2008, p. 251; Matúšová \& Jablonský, 2012, p. 9; Beblavý, 2012, p. 4). It represents

a set of activities and measures which purposefully lead to the personal development, better lifestyle and improvement of living conditions of all inhabitants, as well as to providing the social sovereignty or safety within the given political, economic and social possibilities of the country (Stanek et al., 2008, p. 16).

R. Bednárik (2007, p. 233) offers a broader and narrower perception of this concept. He understands social policy as specific activity of the State, an area or part of the economic policy or a synonym of social security. On the other side, education policy represents

a set of specific activities and measures which the State and other subjects use for influencing the education and educational programme. They also use these measures for deciding about the educational institutions and the approach, aims and contents of education, and also about the way of leading and financing (Matúšová \& Jablonský, 2012, p. 10).

V. Stanek et al. (2008, p. 251) similarly define the education policy. They add that it aims "to ensure developing and spreading of knowledge, skills and competencies significant for the needs of individuals, economics and the society, including also moral, value and cultural aspects”.

V. Stanek et al. (2008, p. 251) state that social changes in Europe have influenced the education system in different ways. For example, the demographic trends (i.e. increase of the average life expectancy and changes in the age structure of the population) have led to the need for lifelong education. The authors also mention that "the education policy belongs to the determinants of economic growth. According to them, "the social benefit of education is generally higher than private profits" (Stanek et al., 2008, p. 252). These examples confirm the connection between social and education policy. 


\section{METHODOLOGY OF RESEARCH}

Our work lies in the principles and methods of comparative andragogy. We analyze the education and social policies of Slovakia, Germany and Spain. Our objective is to identify such areas which are related to active ageing and active old age. Subsequently, we focus on comparing the education and social policies of these European states paying particular attention to the issue of active ageing and active old age. We aim to define their commonalities and differences.

The Department of Adult Education and Personnel Management at Faculty of Arts, Charles University in Prague carried out a similarly aimed comparative research within the VF project called Analysis and Comparison of Forms and Methods for the Education of Older Adults in the V4 Countries. The research team observed the social context of education for older adults, their connection to working life, as well as the system and methods of education for older adults in the V4 countries (Kocianová et al., 2013). M. Leszko and B. Bugajska (2017) carried out another comparative study focused on comparing the policies of employment of older adults in Slovakia, the Czech Republic and Poland. Preparation of Europeans for retirement was the topic of research within the Erasmus+ project called BALL - Be Active Through Lifelong Learning (2015). The research team consisted of organisations coming from Spain, Poland and Island. Their research aimed to provide data about the situation of people shortly before their retiring. Based on the obtained results, the project team suggested such means of education that would help citizens in the pre-retirement age to prepare for retirement, to be active, and to live this life period in the best possible way (BALL - Be Active Through Lifelong Learning, 2015). D. Gracová and E. Selecký (2017) also carried out an exciting and significant comparative research aimed at European universities of the Third Age. Some interesting analyses were published in the almanacs Third Age Education. European, Azerbaijan, Russian and Ukrainian Experience, edited by D. Spulber (2017) and Active Ageing. From Wisdom to Lifelong Learning, edited by G. Amoretti, D. Spulber and N. Varani (2017). The last two publications are from the international TEMPUS project called Centre for the Third Age Education, which was led by the University of Genoa (more about the project: http:// www.tempus-ctae.eu/). In 2018, we published a comparative study, where we focused on the foreign language education of adults as preparation for the old age in Germany and Spain (Határ \& Jedličková, 2018). 
The issue of active ageing and active old age in the education and social policy ...

According to J. Matulčík (2004, p. 53), comparative andragogical research does not substitute historical research; it aims at comparing the current state in education of adults, both at home and abroad. It studies many documents of a different character. Comparative research in andragogy usually goes through the phase of accurate description, interpretation of facts, generalisation, evaluation and modelling (Matulčík, 2004, p. 55). In our work, we used mainly two methods of comparative andragogy mentioned by this author. The first method was the descriptive method. (In the initial processing of the education and social policies of Slovakia, Germany and Spain. It aimed at the issue of active ageing and active old age.) The other method was the comparative method (in the output comparing of common and different features of education and social policies of Slovakia, Germany and Spain in the observed parameters or areas: active ageing and active old age). The descriptive method enables "to describe the educationalformational systems and their components accurately and systematically", on the other hand, the comparative one answers the question which similar and different features the objects of our research possess (Matulćík, 2004, p. 59, 63). We obtained some information related to active ageing and active old age in the education and social policies (legislation) of compared countries via the internet search engine Google, entering various keywords.

Our decision to compare the Slovak education and social policy in the area of active ageing and active old age with German and Spain ones was not coincidental. On one side, we were interested in examples of good practice. On the other side, according to Eurostat, Germany belongs to those EU countries which have the highest values in the numbers of people aged 65+ in the whole population (Eurostat, 2017). In the statistic report Ältere Menschen in Deutschland und der EU [Older people in Germany and the EU] (2016, p. 6), it is mentioned that "in Germany, more than every fourth person belongs to the generation aged 60+. In 2050, more than every third person will belong to this generation. The number of people aged 60+ is going to be higher, for example in Slovakia, Spain, Portugal and Greece”.

\section{ACTIVE AGEING AND ACTIVE OLD AGE IN SLOVAK EDUCATION AND SOCIAL LEGISLATION}

In 2008, the Slovak Government founded The Council of the Government of the Slovak Republic for Seniors. In 2012, The Government Council of the Slovak 
Republic for Human Rights, National Minorities and Gender Equity was established, later (2014) it transformed into The Council of the Government of the Slovak Republic for Seniors' Rights and Adjustments to Public Policies on Aging Population, which exists until now. This council, as a professional, counselling, coordination and initiative organ of the government, deals with several issues, e.g. how to eliminate the negative impact of the ageing process of the population on different areas of social life. The council also focuses on respecting and pursuing the seniors' rights and interests; and participated in the creation and evaluation of the National Programme for Active Ageing, (Štatút Rady vlády Slovenskej republiky pre práva seniorov a prispôsobovanie verejných politík procesu starnutia populácie, 2014).

At the website of The Council of the Government of the Slovak Republic for Seniors' Rights and Adjustments to Public Policies on Aging Population, there can be found the key documents related to the issue of (active) ageing which are binding also for the Slovak Republic. These documents are: Princípy OSN vo vztahu $k$ starším ludom [United Nations Principles for Older Persons] (1991), Odporúčanie Rec(2009)6 Výboru ministrov Rady Európy členským štátom o starnutí a zdravotnom postihnutí v 21. storoči: udržateliné rámce, ktoré umožnia vyššiu kvalitu života v inkluzívnej spoločnosti [Recommendation CM Rec (2009)6 of the Committee of Ministers to member states on ageing and disability in the $21^{\text {st }}$ century: sustainable frameworks to enable greater quality of life in an inclusive society] (2009), Národný program ochrany staršich ludi [National Program for the Protection of the Elderly] (1999), Národný program aktívneho starnutia na roky 2014-2020 [National Programme for active ageing for the years 2014-2020] (2014) and Definícia vekového manažmentu a vytvorenie zásad vekového manažmentu pre zamestnávatelov (v súkromnej a verejnej správe) [Definition of age management and creation of age management principles for employers (in private and public administration)] (2017).

The subject of our analysis at the level of the so-called social policy became the documents Národný program aktívneho starnutia na roky 2014-2020 (2014) and Definícia vekového manažmentu a vytvorenie zásad vekového manažmentu pre zamestnávatelov (v súkromnej a verejnej správe) (2017) because they are explicitly related to the issue we solve in our research project.

In the preamble to the document Národný program aktívneho starnutia na roky 2014-2020 (2014, p. 3), it is mentioned that 
The issue of active ageing and active old age in the education and social policy ...

this is a new and comprehensive programme document aimed at supporting the human rights of older adults and their activation by public support policies. The programme is not only focused on the employment policy of older adults (Strategy of active ageing primarily focuses on this issue), it also deals with their lifelong learning, civic and social activities outside the formal labour market, promoting their independence, dignity, economic and social security, including protection against mistreatment in all relationships and spheres of social life (p. 3).

The lifelong education part contains a recommendation to improve the offer of educational possibilities and to focus on non-formal and professional education for the labour market needs. There are defined six strategical objectives within the lifelong education: 1) To improve the quality of life by creating new possibilities and develop the existing ones for the education for older people; to support their active life and better labour market integration. 2) and 3) Legislation integration of particular types and forms of education for older adults in the education system; to ensure these types and forms economically. 4) To increase the digital literacy of older people. 5) To improve the financial literacy of older people. 6) To develop the professional preparation of career advisors for working with older people (Národný program aktívneho starnutia na roky 2014-2020, 2014, p. 31-34). Based on the ageing of the population, it is very probable that, in 2050, there will be $21 \%$ absence of workforce in Slovakia. For this reason, this national programme emphasises that it is crucial to prepare the employers for this situation.

Another crucial material based on the requirements from the already mentioned document Národný program aktívneho starnutia na roky 2014-2020 (2014, p. 24-25) is the document called Definícia vekového manažmentu a vytvorenie zásad vekového manažmentu pre zamestnávatelov (v súkromnej a verejnej správe) (2017). Here it is stated that we can achieve active ageing also with a longer and better working life of older employees in the following way:

- Strengthening a fair and adequate approach to older employees (aimed at employers and the employees concerned).

- Acquiring effective managing strategies to discover and support the strong points of older employees.

- Taking into consideration the increasing age of leaving to retirement and supporting such working life that is age-friendly (concerning all generations). 
- Supporting active cooperation of all interested stakeholders.

- Supporting the responsibility of social partners in healthcare services and the OSH field (Definícia vekového manažmentu a vytvorenie zásad vekového manažmentu pre zamestnávatel'ov (v súkromnej a verejnej správe), 2017, p. 14).

In the introduction of our study, we mentioned that the so-called education policy is a part of social policy. At this level, we deal more thoroughly with the following documents Stratégia celoživotného vzdelávania [Lifelong Education Strategy] (2011), Akčný plán stratégie celoživotného vzdelávania [Action Plan of Lifelong Education Strategy] (2011) and Národný program rozvoja výchovy a vzdelávania 2018-2027. Kvalitné a dostupné vzdelanie pre Slovensko [National programme for the development of education for the period 2018-2027. High-quality and available education for Slovakia] (2018).

Stratégia celoživotného vzdelávania (2011, p. 36) focuses on the "strengthening of individuals' awareness of the need for permanent education, which provides them with skills and competencies for sustainable employability, for success in society and development of their interests". The given objective focuses on four main priorities of lifelong education: 1) the attractiveness of lifelong education, 2) the relevance of education for the labour market and engaging in the society, 3) availability of counselling services and 4) continuous access to lifelong education (Stratégia celoživotného vzdelávania, 2011, p. 36-38; Akčný plán stratégie celoživotného vzdelávania, 2011, p. 2), which are explained in more detail in the document Akčný plán stratégie celoživotného vzdelávania (2011, p. 3-9).

The newest strategical document in the field of regional and higher education and partly also in further education in Slovakia is the document called Národný program rozvoja výchovy a vzdelávania 2018-2027. Kvalitné a dostupné vzdelanie pre Slovensko (2018). This document contains three strategic objectives: 1) high quality, 2) availability and 3) modernisation of education. There are three cross-cutting priorities: "1) integration and inclusion of the marginalised Roma communities and students from disadvantaged social background, 2) connection of the education system with the needs of economics and labour market, 3) development of the nonformal education system” (Národný program rozvoja výchovy a vzdelávania 2018-2027. Kvalitné a dostupné vzdelanie pre Slovensko, 2018, p. 37-38). The last priority directly connects to the topic of our work. The national 
programme also aims at "the support of structured forms of further education and development of the system of recognition and verification of qualifications” (Národný program rozvoja výchovy a vzdelávania 2018-2027. Kvalitné a dostupné vzdelanie pre Slovensko, 2018, p. 44). Unfortunately, in this document, the further education of adults finishes at the age of 64 years. In this case, we can speak about the active old age only with significant limitations (more about the document and its attachments: https://www. minedu.sk/17786-sk/narodny-program-rozvoja-vychovy-a-vzdelavania/). On the website of the Ministry of Education, Science, Research and Sport of the Slovak Republic, we can find a direct link to the Electronic Platform for Adult Learning in Europe (EPALE). There it is possible to follow not only events and activities prepared in the field of adult learning, but, in the section Sources, there are also published reports, concepts, documents or legislative measures to support the education of adults (more about the platform: https:// epale.ec.europa.eu/sk). One of them is the document Manifesto for Adult Learning in the 21st century: The Power and Joy of Learning (2019, p. 18), it mentions that the European Association for the Education of Adults

is committed to active ageing and encourages a common vision on the active participation of older people. Learning provides many of these opportunities, and active ageing will only be guaranteed if learning in later life is provided. Research shows that learning seniors are more active, have more social contacts, volunteer more, work longer and are healthier. It is, therefore, essential to provide high-quality learning opportunities for all older people, which, in turn, will need the necessary framework of policies, funding, structures and access. Even at a very old age, learning has positive impacts (p. 18).

The following documents also belong to the essential documents in this area: Memorandum o celoživotnom vzdelávaní sa [A Memorandum on Lifelong Learning] (2000), Active Ageing: A Policy Framework (2002) or Active Ageing Index for 28 European Union Countries (2014). We offer their analysis in our other studies (e.g. Határ \& Grofčíková, 2016; Határ, 2019). 


\section{ACTIVE AGEING AND ACTIVE OLD AGE IN THE EDUCATION AND SOCIAL LEGISLATION OF GERMANY}

In 2017, the Federal Ministry for Family Affairs, Senior Citizens, Women and Youth published the Round Table report called Aktives Altern - Übergänge gestalten [Active Ageing - Shaping transitions]. Three expert working groups worked on this report for two years. They formulated ten recommendations or conclusions in the following areas: 1) municipal framework conditions, 2) credible and reliable data, 3) Active Ageing Index adapted to municipalities, 4) municipal care about living conditions, 5) improved policy regulations, 6) education, 7) information and communication technologies, 8) occupational/personal policy adequate for ageing and focused on all life periods, 9) preparation for leaving from working life by further education and 10) participation of all older adults. It is essential to mention that education plays a significant role in several recommendations. However, it has a dominant position mainly in points 6,8 and 9 . These recommendations directly refer to education, preparation for retirement and age management. Our research task deals with these topics, as well. As mentioned above, three working groups collaborated in the creation of these recommendations. One of them was the group called Education in the old age and for the old age. Their objective was to highlight action approaches and action opportunities in the areas such as political education, information and communication technologies, preparation for the transition from working life to retirement using measures of further education (Aktives Altern - Übergänge gestalten, 2017, p. 12-13).

The Round Table report Aktives Altern - Übergänge gestalten (2017, p. 9) represents a supplement attached to the document Jedes Alter zählt. Die Demografiestrategie der Bundesregierung [Every Year Counts. The Federal Government's Demographic Strategy] (2017). This document from the Federal Ministry of the Interior contains strategic measures of ten working groups. For us, the conclusions of the three working groups were highly interesting. The working group called Motivated, skilled and healthy workers defined and analysed the following areas: health and prevention at the workplace; treatment of employees who are ill; promotion of entrepreneurship (with particular emphasis on small and medium-sized enterprises) and work organisation related to age and ageing. The last area is significant for age 
The issue of active ageing and active old age in the education and social policy ...

management. Another working group called Living independently in old age was dealing with the housing issues, healthcare, research, and also with better accessibility and cooperation. Promoting educational biographies is the last group we analysed. They focused on the following topics: occupational and study orientation/counselling; occupational and study orientation/counselling for people with weaker performance; counselling for people who left school; counselling in further education of adults; educational counselling in the municipal system and counselling for refugees (Jedes Alter zählt. Die Demografiestrategie der Bundesregierung, 2017, p. 21-31, 57-61). When compared with this strategy, it is essential to mention that the document Aktives Altern - Übergänge gestalten (2017) is more specific and focused exclusively on ageing and old age.

\section{ACTIVE AGEING AND ACTIVE OLD AGE IN THE EDUCATION AND SOCIAL LEGISLATION OF SPAIN}

In the plenary 2017, the State Council of Older Persons approved a document called Estrategia Nacional de Personas Mayores para un Envejecimiento Activo y para su Buen Trato 2018-2021 [National Strategy for Older Adults for an Active Ageing and for their good 2018-2021]. We mention the most relevant challenges in this document:

- to provide seniors with equal opportunities and dignified life in all spheres of social life;

- to guarantee the active participation of seniors in all activities of public life and governance if these are directly related to them and have an impact on their life;

- to support the stay of older people in the natural environment of their families and communities as long as possible;

- to allow seniors' participation in social life in such a way so that society could use their rich experience and knowledge;

- to promote the interest of state and private institutions in seniors to offer suitable programmes and services for this target group;

- to guarantee social protection and security for the senior population;

- to avoid age discrimination;

- to prevent, diagnose and eliminate the mistreatment and abuse of old people;

- to keep the quality of life for seniors by financial security and dignified retirement, as stated in the Constitution; 
- to apply effective measures to support the healthy process of active ageing (Estrategia Nacional de Personas Mayores para un Envejecimiento Activo y para su Buen Trato 2018-2021, 2017, p. 7 - 8).

The Spanish Association of Universities of the Third Age offers preparation courses for retirement. They aim to raise the awareness of employees who will be retired soon and to prepare them adequately for retirement, which should be dignified, well-balanced and meaningful. These courses also prepare their family members for this upcoming situation. They provide seniors with numerous alternatives on how to organise their life and free time actively and creatively. They deal with specific problems which are directly related to the senior population at the beginning of their retirement. These courses offer many possibilities of developing general health, personal well-being and good quality of life. They inform employees in the pre-retirement age about all issues they need to know before they get retired. They try to alleviate their worries and bespeak their physical, mental and social health during the retirement period (http://ceate.es/proyectos-y-programas/cursosde-formacion/). On their website, there are also the educational contents and topics of all meetings:

1) Retirement - a challenge for modern societies: employees in the pre-retirement age; problems and possibilities of the retirement period of life; preparation for retirement;

2) Psychology of ageing and retirement period of life: psychological and sociological factors of retirement, overcoming of the perception of retirement as a period of loss, nonsense, decay or deficit; healthy versus pathological ageing;

3) Preventive medicine and nutrition and retirement: health, well-being, adequate quality of life in retirement; preventive care, hygiene and rehabilitation; nutrition and dietetics;

4) Social resources and services for seniors:centres, facilities and organisations for seniors; programmes of volunteering for seniors as participants of voluntary activities and as a target group, universities of the Third Age;

5) Culture, hobbies and free time during the retirement period: creative-recreational, sport, formational-cultural, civic and touristic activities (http://ceate.es/proyectos-y-programas/cursos-de-formacion/). 
The issue of active ageing and active old age in the education and social policy ...

The target group that can participate in these courses consists of the following groups of population: people above the age of 50, employees in the pre-retirement age, seniors who have recently finished their active working life (http://ceate.es/proyectos-y-programas/cursos-de-formacion/).

Another example of good practice is the course of preparation for retirement called Programme Apol-lónia, which takes place in Barcelona, and it aims at retired dentists (Calvo, Pareja, \& Gómez, 2018).

\section{CONCLUSION}

S. Matúšová and T. Jablonský (2012, p. 110) say that

until the Treaty of Lisbon entered into force, the education policy of the European Union was considered a policy subject to the principle of subsidiarity. According to this principle, the competencies were distributed between the member states and the European Union. With its support measures, the European Union complemented the education policy of its member countries (p. 110).

The authors also mention that the development of the European Community and European Union contributed to the connection of education policies with other policies. For example, this connection became significant also in the case of adaptation of the professional preparation and re-training of employees in the retirement age to new requirements at the labour market (Matúšová \& Jablonský, 2012, p. 113).

In the following table, we offer a summary of common features we obtained from the comparison of active ageing, active old age and, partially, also age management in the education and social policies of Slovakia, Germany and Spain. We did not identify any different features in the examined area between the compared countries.

J. Ilmarinen (2008, p. 50) says that

the policy of active ageing in the European Union is based on reinforcing the control mechanisms of early retirement and improvement of work benefits. It also focuses on the right and the need for lifelong education, good working conditions, flexible working life, as well as the availability of healthcare and social services. Work incentives should be developed in such a way so that further continuation of work was a real choice for people (p. 50). 


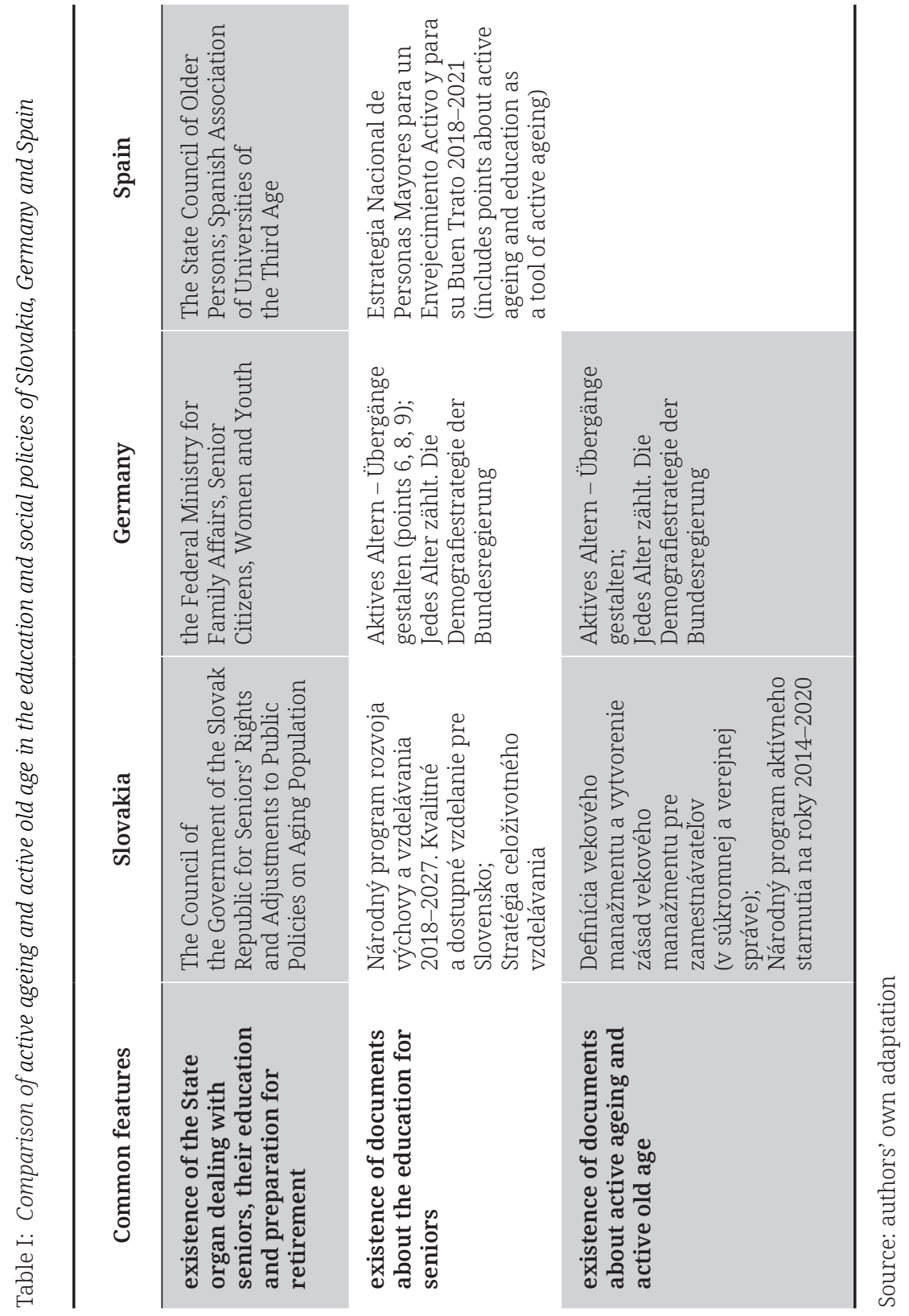


Although we are aware of the gravity of the situation, we do not think that it is correct to look at active ageing and active old age only from the perspective of continuous activity of employees - retired people at the labour market. P. Taylor (2002, in: Ilmarinen, 2008, p. 49-50) recommends the following steps to improve the age policy:

- It is crucial to finance active age policy adequately.

- All political sectors should participate in the creation of policy related to ageing.

- Programmes for ageing people should improve their diversity, and they should represent part of the diversity of working life.

- It is significant to create these programmes from the micro-level up to the macro-level.

- The flexibility of models and solutions should be the key feature of these programmes.

- Programmes should emphasize the prevention of problems.

- It is also desirable to verify and evaluate these programmes.

- Other features of these programmes include their consistency, durability and positive character.

J. Ilmarinen (2008, p. 50) also mentions that Finland followed these recommendations in the creation of their programmes which got many awards, and they became the subject of research as well. Maybe positive experience from foreign social and education policies could facilitate the progress of the Slovak social and education policy focused on active ageing, active old age and age management. On the other hand, Slovakia has much to offer to Europe in solving this problem as well.

\section{Acknowledgement}

The study presented here was published within the research task VEGA of the Ministry of Education, Science, Research and Sport of the Slovak Republic and the Slovak Academy of Science no. 1/0001/18 called Preparation for ageing and old age - possibilities of andragogical intervention. 


\section{REFERENCES}

Active ageing: A policy framework. (2002). Available from: http://apps.who.int/ iris/bitstream/10665/67215/1/WHO_NMH_NPH_02.8.pdf

Active ageing index for 28 European Union countries. (2014). Available from: https://www.unece.org/fileadmin/DAM/pau/age/WG7/Documents/Policy_ Brief_AAI_for_EG_v2.pdf

Akčný plán stratégie celoživotného vzdelávania. (2011). Available from: https:// www.minedu.sk/data/files/2606_akcny-plan-strategie-czv-2011_final.pdf Aktiv Altern: Rahmenbedingungen und Vorschläge für politisches Handeln. (2002). Available from: http://apps.who.int/iris/bitstream/10665/67215/2/ WHO_NMH_NPH_02.8_ger.pdf

Aktiv im Alter. Runder Tisch „Aktives Altern - Übergänge gestalten“. (2020). Available from: https://www.bmfsfj.de/bmfsfj/themen/aeltere-menschen/ aktiv-im-alter/runder-tisch-aktives-altern-uebergaenge-gestalten

Aktives Altern - Übergänge gestalten. (2017). Available from: https://www. bmfsfj.de/blob/117360/51d4f9b4b365930e77901fed25184b70/runder-tischaktives-altern-ergebnispapier-data.pdf

Amoretti, G., Spulber, D., \& Varani, N. (Eds.) (2017). Active ageing. From wisdom to lifelong learning. Roma: Carocci editore S.p.A.

Ältere Menschen in Deutschland und der EU. (2016). Available from: https:// www.bmfsfj.de/blob/93214/95d5fc19e3791f90f8d582d61b13a95e/aelteremenschen-deutschland-eu-data.pdf

BALL - Be active through lifelong learning. (2020). Available from: https://www. ball-project.eu/es

Balogová, B. (2005). Seniori. Prešov: AKCENT PRINT.

Beblavý, M. (2012). Sociálna politika. Available from: https://www. researchgate.net/publication/311569587_Socialna_politika/ link/584d54ff08ae4bc8992f5e09/download

Bednárik, R. (2007). Teória sociálnej politiky. In Tokárová, A., et al. Sociálna práca. Kapitoly z dejín, teórie a metodiky sociálnej práce (pp. 232-241). Prešov: AKCENT PRINT.

Blusková, J. (2017). Komparácia edukácie seniorov na Slovensku a v Rakúsku. In Juvenilia paedagogica 2017 (pp. 18-22). Trnava: Trnavská univerzita. Available from: http://pdf.truni.sk/katedry/kps/veda-vyskum?juveniliapaedagogica\#2017 
The issue of active ageing and active old age in the education and social policy ...

Bútorová, Z., et al. (2013). Štvrtý rozmer tretieho veku. Desat' kapitol o aktívnom starnutí. Bratislava: Inštitút pre verejné otázky.

Calvo, A., Pareja, G., \& Gómez, A. (2018). Programa Apol-lónia. Available from: http://www.coec.cat/wp-content/uploads/2018/01/programa_curspreparacio-jubilacio_es.pdf

Centre for the third age education. (2020). Available from: http://www.tempusctae.eu/

Cimbálníková, L., et al. (2011). Age Management: Komparativní analýza podmínek a prístupů využivaných v České republice a ve Finsku. Praha: AIVD ČR. Available from: http://www.aivd.cz/soubor-doc738/

Cimbálníková, L., et al. (2012). Age Management pro práci s cílovou skupinou 50+ Metodická př́ručka. Praha: AIVD ČR. Available from: http://www.aivd. cz/soubor-doc737/

Cursos de Preparación a la Jubilación. (2020). Available from: http://ceate.es/ proyectos-y-programas/cursos-de-formacion/.

Čornaničová, R. (1998). Edukácia seniorov. Vznik, rozvoj, podnety pre geragogiku. Bratislava: UK.

Definícia vekového manažmentu a vytvorenie zásad vekového manažmentu pre zamestnávatelov (v súkromnej a verejnej správe). (2017). Available from: https://www.employment.gov.sk/files/slovensky/ministerstvo/rada-vlady-srprava-seniorov/definicia-vekoveho-manazmentu-vytvorenie-zasad.pdf

Elektronická platforma vzdelávania dospelých v Európe (EPALE). (2020). Available from: https://epale.ec.europa.eu/sk

Estrategia Nacional de Personas Mayores para un Envejecimiento Activo y para su Buen Trato 2018-2021. (2017). Available from: https://www.fundadeps. org/recursos/documentos/844/02EFE9D3.pdf

Eurostat. (2017). Štruktúra a starnutie obyvatel'stva. Available from: https:// ec.europa.eu/eurostat/statistics-explained/index.php?title=Population_ structure_and_ageing/sk

Gracová, D., \& Selecký, E. (2017). Vývojové trendy edukácie seniorov na univerzitách tretieho veku v Európe. Banská Bystrica: Belianum.

Grenčíková, A., \& Španková, J. (2012). Prispôsobovanie vzdelávania potrebám ekonomiky. Sociálno-ekonomická revue/Social and Economic Revue, 10(3), 34-39. Available from:

https://fsev.tnuni.sk/fileadmin/veda_a_vyskum/SER/2012/Socialno_ ekonomicka_revue_volume_3_2012.pdf\#page=34 
Hanobik, F. (2016). Sociálna politika EÚ a multikultúrnost'. Příbram: Ústav sv. Jana Nepomuka Neumanna.

Határ, C. (2014). Podpora aktívnej participácie seniorov na spoločenskom živote prostredníctvom edukácie. In Balogová, B., \& Skyba, M. (Eds.), Sociálny kapitál starnutia - prítomnost́ nikdy nestarne (pp. 175-191). Prešov: Prešovská univerzita.

Határ, C. (2019). Active ageing and active old age in the educational context. AD ALTA, 9(1), 97-102. Available from: http://www.magnanimitas.cz/ ADALTA/0901/papers/A_hatar.pdf

Határ, C., \& Grofčíková, S. (2016). Foreign language education of seniors. JoLaCE, 4(1), 158-179. Available from: https://content.sciendo.com/configurable/ contentpage/journals $\$ 002$ fjolace $\$ 002 f 4 \$ 002 f 1 \$ 002$ farticle-p110.xml

Határ, C., \& Jedličková, P. (2018). Cudzojazyčné vzdelávanie dospelých ako príprava na starobu v Nemecku a Španielsku. In Veteška, J. (Ed.), Adult education 2017 - in time of resonant social changes (pp. 165-175). Praha: Česká andragogická společnost.

Ilmarinen, J. (2008). Ako si predižit aktívny život. Starnutie a kvalita pracovného života v Európskej únii. Bratislava: Príroda.

Jedes Alter zählt. Die Demografiestrategie der Bundesregierung. Arbeitsgruppenergebnisse zum Demografiegipfel am 16. März 2017. (2017). Available from: https://www.bmfsfj.de/blob/137854/d54ed3c30 bef003b10abb00df394ae4b/demografiestrategie-der-bundesregierungdata.pdf

Kocianová, R., et al. (2013). Analysis and comparison of forms and methods for the education of older adults in the V4 countries. Praha: Filozofická fakulta Univerzity Karlovej.

Krystoň, M. (2015). Vzdelávatelia seniorov. Paper presented at the international scientific conference Adult Education 2015 (9.4.2015 Banská Bystrica).

Leszko, M., \& Bugajska, B. (2017). The evaluation of employment policies for older adults in the Czech Republic, Poland and Slovakia. In Tomczyk, L., \& Klimczuk, A. (Eds.), Selected Contemporary Challenges of Ageing Policy (pp. 69 - 87). Kraków: Uniwersytet Pedagogiczny. Available from: https://gerontolodzy.files.wordpress.com/2018/09/final-sklad-selectedcontemporary-challenges-of-ageing-policy.pdf

Manifesto for adult learning in the 21st century: The power and joy of learning. (2019). Available from: https://eaea.org/wp-content/uploads/2019/04/eaea_ manifesto_final_web_version_290319.pdf 
The issue of active ageing and active old age in the education and social policy ...

Manifest pro vzdělávání dospělých ve 21. století: Silla a radost vzdělávání. (2019). Available from: https://eaea.org/wp-content/uploads/2020/01/eaea_ manifesto_czech_091019.pdf

Masárová, T. (2012). Kvalita života verzus kvalita sociálnych procesov. Sociálno-ekonomická revue/Social and Economic Revue, 10(3), 80-86. Available from: https://fsev.tnuni.sk/fileadmin/veda_a_vyskum/SER/2012/Socialno_ ekonomicka_revue_volume_3_2012.pdf\#page=80

Matulay, S., \& Matulayová, T. (2004). Vybrané kapitoly zo sociálnej politiky a katolíckej sociálnej náuky. Nitra: Univerzita Konštantína Filozofa.

Matulčík, J. (2004). Teórie výchovy a vzdelávania dospelých v zahraničí. Bratislava: Gerlach Print.

Matúšová, S., \& Jablonský, T. (2012). Vzdelávacia politika Európskej únie. Ružomberok: VERBUM.

Memorandum o celoživotnom vzdelávaní sa. (2000). Available from: https:// www.minedu.sk/data/files/2607_2000_memorandum_o_celozivotnom_ vzdelavani.pdf

Národný program aktívneho starnutia na roky 2014-2020. (2014). Available from: https://www.employment.gov.sk/files/slovensky/ministerstvo/radavlady-sr-prava-seniorov/npas-2014-2020.pdf

Národný program ochrany starších ludí. (1999). Available from: https://www. employment.gov.sk/files/5578_subor.pdf

Národný program rozvoja výchovy a vzdelávania 2018-2027. Kvalitné a dostupné vzdelanie pre Slovensko. (2018). Available from: https://www.minedu.sk/data/ att/13285.pdf; https://www.minedu.sk/17786-sk/narodny-program-rozvojavychovy-a-vzdelavania/

Novotný, P., et al. (2014). Age management: Jak rozumět stárnutí a jak na něj reagovat. Možnosti uplatnění age managementu v České republice. Průvodce pro jednotlivce, organizace a společnost. Praha: AIVD ČR. Available from: http://www.aivd.cz/soubor-doc736/

Odporúčanie Rec(2009)6 Výboru ministrov Rady Európy členským štátom o starnutí a zdravotnom postihnutí v 21. storoči: udržatelné rámce, ktoré umožnia vyššiu kvalitu života v inkluzívnej spoločnosti. (2009). Available from: https://www.employment.gov.sk/files/slovensky/ministerstvo/poradneorgany/ludske-prava-narodnostne-mensiny-rodovu-rovnost-sr/vyborseniorov/rec20096.pdf

Porubská, G., \& Ďurdiak, L. (2005). Manažment vzdelávania dospelých. Nitra: SlovDidac. 
Princípy OSN vo vztahu k starším ludom. (1991). Available from: https://www. employment.gov.sk/files/slovensky/ministerstvo/poradne-organy/ludskeprava-narodnostne-mensiny-rodovu-rovnost-sr/vybor-seniorov/principyosn-vo-vztahu-k-starsim-ludom.pdf

Rada vlády Slovenskej republiky pre práva seniorov a prispôsobovanie verejných politík procesu starnutia populácie. (2020). Available from: https:// www.employment.gov.sk/sk/ministerstvo/rada-vlady-sr-prava-seniorov/

Schunová, R. (2019). Analýza dokumentov o aktívnom starnutí na Slovensku a v zahraničí. In Mayer, K. (Ed.), Teória a prax edukácie dospelých (pp. 161-170). Prešov: Prešovská univerzita. Available from: http://www.pulib. sk/web/pdf/web/viewer.html?file=/web/kniznica/elpub/dokument/Mayer2/ subor/zbornik.pdf

Spulber, D. (Ed.) (2017). Third age education. European, Azerbaijan, Russian and Ukrainian experience. Roma: Carocci editore S.p.A.

Stanek, V., et al. (2008). Sociálna politika. Bratislava: Sprint dva.

Stratégia celoživotného vzdelávania. (2011). Available from: http://old.minedu. sk/data/USERDATA/DalsieVzdel/VDOC/Strategia\%20celozivotneho\%20 vzdelavania\%202011.pdf

Šerák, M., \& Tomczyk, L. (Eds.). (2019). Preparation to ageing and old age. Kraków: UP. Available from: https://www.researchgate.net/ publication/337389448_PREPARATION_TO_AGEING_AND_OLD_AGE/ link/5dd51914299bf11ec8630893/download

Štatút Rady vlády Slovenskej republiky pre práva seniorov a prispôsobovanie verejných politík procesu starnutia populácie. (2014). Available from: https://www.employment.gov.sk/files/legislativa/dokumenty-zoznamy-pod/ statut.pdf

Štatút Rady vlády Slovenskej republiky pre seniorov. (2008). Available from: https://lrv.rokovania.sk/12936/17-/?cms_location=12936/17-

Štatút Výboru pre seniorov. (2012). Available from: https://www.employment. gov.sk/files/slovensky/ministerstvo/poradne-organy/ludske-pravanarodnostne-mensiny-rodovu-rovnost-sr/vybor-seniorov/statut-vyborupre-seniorov.pdf

Švec, Š. (2008). Anglicko-slovenský lexikón pedagogiky a andragogiky. Bratislava: Iris.

Švec, Š., et al. (1998). Metodológia vied o výchove. Kvantitatívno-scientické a kvalitatívno-humanitné prístupy v edukačnom výskume. Bratislava: IRIS. 
Tokárová, A., et al. (2007). Sociálna práca. Kapitoly z dejín, teórie a metodiky sociálnej práce. Prešov: AKCENT PRINT.

Tomeš, I., Šámalová, K. (Eds.), et al. (2017). Sociální souvislosti aktivního stář́. Praha: UK Karolinum.

Kontakt

prof. PaedDr. Ctibor Határ, PhD.: chatar@ukf.sk

PhDr. Petra Jedličková, PhD.: pjedlickova@ukf.sk 